\title{
Gillnet selectivity for non target fish species caught by red mullet gillnets north Aegean Sea
}

\section{Kuzey Ege Denizi'nde barbun uzatma ağlarında yakalanılan hedef dışı türlerin seçiciliği}

\author{
Engin Kocabaş ${ }^{1}$ (D) Alkan Öztekin² (D) İsmail Burak Daban ${ }^{2}$ (D) Adnan Ayaz² \\ 1 Republic of Turkey Ministry of Food, Agriculture and Livestock, Bandırma Sheep Breeding Research Institute, Fisheries Department, Balıkesir - Turkey \\ ${ }^{2}$ Çanakkale Onsekiz Mart University, Marine Sciences and Technology Faculty, Fisheries and Fish Processing Department, Çanakkale - Turkey \\ *Corresponding author: burakdaban@comu.edu.tr
}

\section{How to cite this paper:}

Kocabaş, E., Öztekin, A., Daban, İ.B. \& Ayaz, A. (2018). Gillnet selectivity for non target fish species caught by red mullet gillnets north Aegean Sea. Ege Journal of Fisheries and Aquatic Sciences, 35(3), 319-326. DOI:10.12714/egejfas.2018.35.3.12

\begin{abstract}
The aim of this study is to determine the effects of red mullet gillnets that commonly used in Turkish waters on sustainability of non target fish species. For these purpose, surveys were realized with $18-20-22 \mathrm{~mm}$ nominal bar length red mullet gillnets between December 2008 and May 2010 along the north Aegean Sea coasts $(5-30 \mathrm{~m})$. SELECT method was used with five different model (Normal location, normal scale, log-normal, gamma and bi-modal) for evaluating selectivity parameters of non target fish species. Selectivity models were determined as bi-modal for Serranus scriba and Symphodus tinca, log normal for Scorpaena porcus and Spicara maena and gamma for Pagellus acarne. Optimum catch lengths and spread values and selectivity curves were given for 5 species. Results showed that use of a larger mesh size over the $22 \mathrm{~mm}$ mesh is important for ensuring stock sustainability of the non target fish species.
\end{abstract}

Keywords: Gillnet, selectivity, optimum catch length, non target fish species,

Öz: Bu çalışmada yaygın olarak kullanılan barbun uzatma ağlarının hedef dışı balık türlerinin sürdürülebilirliğine olan etkisinin belirlenmesi amaçlanmıştır. Bu amaçla, kuzey Ege Denizi kıyılarında (5-30 m.) Aralık 2008 - Mayıs 2010 tarihleri arasında $18-20-22 \mathrm{~mm}$ göz genişliğine sahip barbun uzatma ağları ile denemeler gerçekleş̧irilmiş̧tir. Hedef dişı türlerin seçicilik parametrelerinin tespitinde 5 farklı model ile (normal location, normal scale, gamma, log-normal ve bimodal) SELECT tahmin metodu kullanılmışıı. Yakalanan çizgili hani ve çırçır için bi-modal, iskorpit ve izmarit için log-normal, yabani mercan için ise gamma en uygun seçicilik modeli olarak belirlenmiş̧ir. 5 tür için optimum yakalama boyları ve yayılım değerleri ile seçicilik eğrileri verilmiştir. Çalışma sonucunda barbun avcılığında kullanılan uzatma ağlarında ağ göz genişliğinin 22 mm'nin üzerine çıkarımasının ilgili türlerin stok sürdürülebilirliği bakımından önemli olduğu tespit edilmiştir.

Anahtar kelimeler: Uzatma ağı, seçicilik, optimum yakalama boyu, hedef dışı balık türleri,

\section{INTRODUCTION}

Gillnets are one of the most widely used fishing gear over the world due to their low costs and easy to use (Hamley, 1975; Reis and Pawson, 1992; Hovgard and Lassen, 2000). Because of the pronounced size selectivity by comparison with the other fishing gears (Guland, 1983), gillnets are extremelly important with regard to sustainable fisheries. In order to develop suitable management strategy in fisheries, the selectivity properties of whole fishing gears should be known by management authority (Millar, 1992; Millar and Holst, 1997). Although methods of the estimation of selectivity has been used for a long times, estimation of the gillnet selectivity studies were increased with the development of the SELECT method since 1990 (Millar, 1992; Millar and Holst, 1997). Selectivity studies of gillnets are especially stick to target species. Gillnets are effective fishing gears in the multi species fishing fields. Besides, proven of single species management approach with the gillnets have not been discussed enough yet.

Gillnets are commonly used fishing gears in the Mediterranean Sea ( Martin et al., 1999; Papaconstantinou and Farrugio, 2000; Sbrana et al., 2007; Karakulak and Erk, 2008; Ayaz et al., 2010b) that known as multi species fishing field. Discard rate was calculated as $15 \%$ by Kelleher (2005) around Mediterranean and Black Sea, whereas 58\% (Ayaz et al., 2010a), 56\% (Aydın et al., 2008) and 77.4\% - 81.4\% (Aydın et al. 2013) in red mullet gill nets Turkish coasts of the Aegean Sea. 
It may not be right to implement a management plan considering only the target species because of the high nontarget rate of multispecies fishing fields. Therefore the right approach with the viewpoint of ecological sustainability might be consider of the selectivity for each species that have high catch rates from the gillnets. The first information deal with selectivity of the Symphodus tinca and Scorpaena porcus in this study, contribute this consideration.

In this context, the aim of this study is to determine the effects of gillnets on the stocks of fish species of red mullet gill nets with the viewpoint of ecosystem based fisheries management.

\section{MATERIALS AND METHOD}

Survey was conducted between December 2008 and May 2010 along the commercial fisheries coasts of Çanakkale, North Aegean Sea. Substratum type of habitats consist of sandy beaches, rocky shores and seagrass beds. Samples were collected by gillnets from 7 stations and 65 operations between 5-30 m depts (Fig. 4). Gillnets were made of multiflament nylon with a twine diameter $210 \mathrm{~d} / 2$. Three different gillnets each with a 40 mesh height were used, the nominal bar length of which were 18,20 and $22 \mathrm{~mm}$ with hanging ratio 0.50 (Fig. 1,2 and 3).
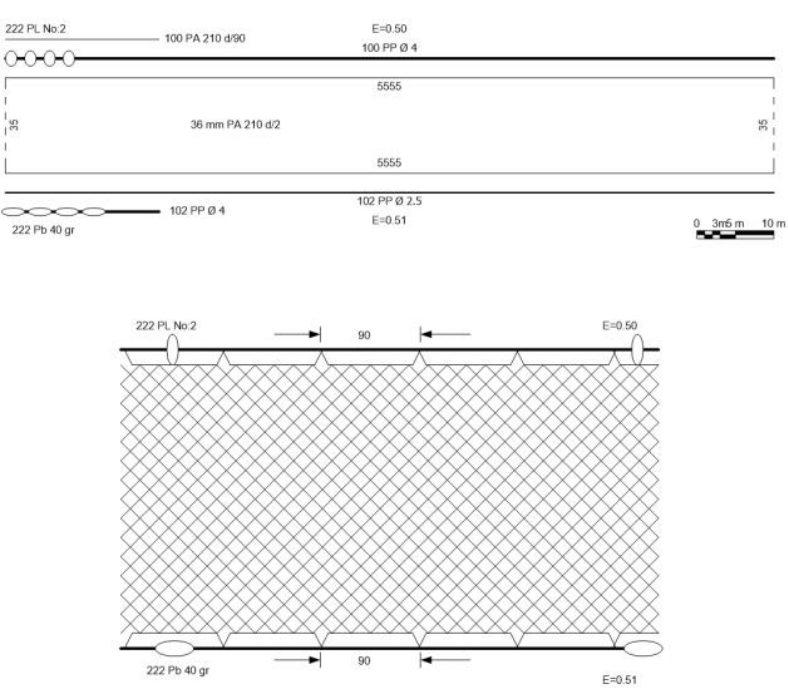

Figure 1. Technical plan of the $18 \mathrm{~mm}$ nominal bar length red mullet gill net

Due to the target species of red mullet gillnets were only mullet species (Mullus spp.), apart from these all species were evaluated as non target fish species. Nets were used as passive and were set parallel to coast at the bottom as Sshaped. Operations were realized 3 hours before dawn and dusk. The soaking time was approximately 3 hours per nets.

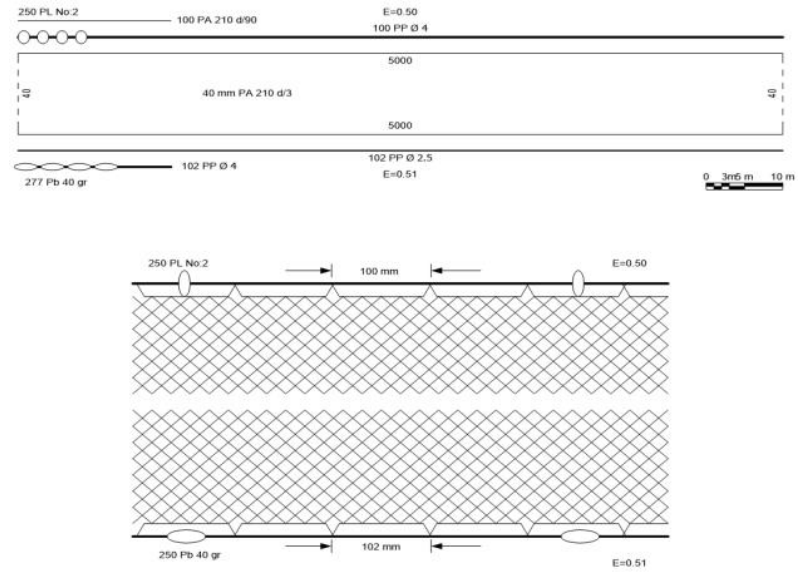

Figure 2. Technical plan of the $20 \mathrm{~mm}$ nominal bar length red mullet gill net
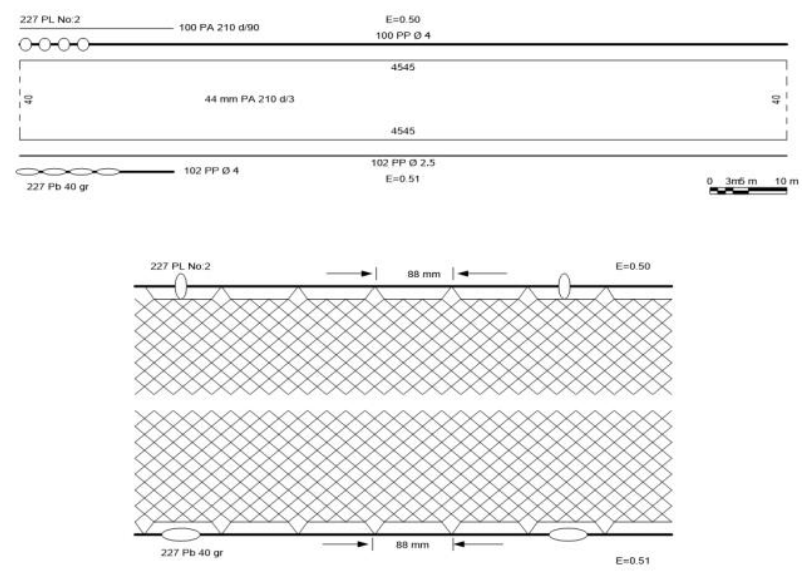

Figure 3. Technical plan of the $22 \mathrm{~mm}$ nominal bar length red mullet gillnets

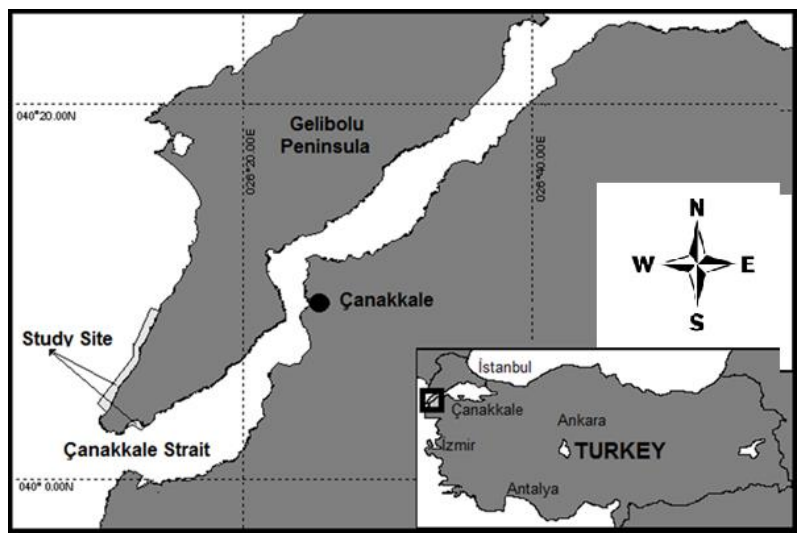

Figure 4. Study area and and general view of the Northern Aegean coasts of Turkey 
The total length was measured with millimetric measurement board and weighed to the nearest $1 \mathrm{~g}$ with digital scales. Length frequency class values calculated from the individuals that sampled varied nominal bar lengths. In the calculation of selectivity parameters, SELECT (Share Each Lengthclass Catch Total) method was used (Millar, 1992; Millar and Fryer, 1999; Millar and Holst, 1997). In this method, be assumed that the number of length / fish caught in gillnet j, have one $n_{l j}$ Poisson distribution and is then distributed as;

$$
\mathrm{n}_{\mathrm{lj}} \approx \mathrm{n}_{\mathrm{lj}} \approx \text { Pois }\left(p_{\mathrm{j}} \lambda_{\mathrm{l}} r_{\mathrm{j}}(I)\right)
$$

where; abundance of length / fish was caught in gillnet $\lambda_{\text {l, is }}$ the relative fishing intensity of gillnet $j, p_{j}$, is the selectivity curve of gillnet $j, r_{j}(I)$

log-likelihood distribution of $n_{l j}$ as;

$$
\sum_{l} \sum_{j}\left\{n_{l} \log \left[p_{j} \lambda_{l} r_{j}(l)\right]-p_{j} \lambda_{l} r_{j}(l)\right\}
$$

Statistical analyses were conducted with PASGEAR II version 2.5 (Kolding and Skålevik, 2011). The SELECT method was used to evaluate selectivity parameters as five different model (Normal location, normal scale, log-normal, gamma and bi-modal). The most suitable model was selected by taking into consideration of minimum deviation value.

Normal Location :

$\exp \left(-\frac{\left(L-k \cdot m_{j}\right)^{2}}{2 \sigma^{2}}\right)$

Normal Scale ;

$\exp \left(-\frac{\left(L-k_{1} \cdot m_{j}\right)^{2}}{2 k_{2}^{2} \cdot m_{j}^{2}}\right)$

Log-Normal ; $\quad[\&$

$\frac{1}{L} \exp \left(\mu+\log \left(\frac{m_{j}}{m_{1}}\right)-\frac{\sigma^{2}}{2}-\frac{\left(\log (L)-\mu-\log \left(\frac{m_{j}}{m_{1}}\right)\right)^{2}}{2 \sigma^{2}}\right)$

Gamma ;

$$
\left(\frac{L}{(\alpha-1) \cdot k \cdot m_{j}}\right)^{\alpha-1} \exp \left(\alpha-1-\frac{L}{k \cdot m_{j}}\right)
$$

Bi-modal ;

$$
\exp \left(-\frac{\left(L-k_{1} \cdot m_{j}\right)^{2}}{2 k_{2}^{2} \cdot m_{j}^{2}}\right)+c \cdot \exp \left(-\frac{\left(L-k_{3} \cdot m_{j}\right)^{2}}{2 k_{4}^{2} \cdot m_{j}^{2}}\right)
$$

\section{RESULTS}

A total of 1452 non target fish species individual representing 5 species were sampled from the red mullet gill nets with $18-20-22 \mathrm{~mm}$ nominal bar lengths. Species were consist of Serranus scriba, Symphodus tinca, Spicara maena, Scorpaena porcus and Pagellus acarne with 403, 207, 576, 107 and 159 individual, respectively. S. scriba individuals were ranged between 11.3 and $29.7 \mathrm{~cm}$ in length, 22 and $441 \mathrm{~g}$ in weigth. S. tinca were ranged between 9.5 and $18.8 \mathrm{~cm}$ in length, 17 and $122 \mathrm{~g}$ in weight. $S$. maena were ranged between 9.8 and $19.5 \mathrm{~cm}$ in length, 10 and $93 \mathrm{~g}$ in weight. $S$. porcus were ranged between 10.1 and $28 \mathrm{~cm}$ in length, 19 and $471 \mathrm{~g}$ in weight. Lastly, $P$. acarne were ranged between 12.8 and 18.5 $\mathrm{cm}$ in length, 22 and $80 \mathrm{~g}$ in weight (Table 1).

Frequency values of non target fish species were calculated due to the length groups. Peak length values of non target fish species differ according to nominal bar length. $P$. acarne, $S$. porcus, $S$. maena and $S$. tinca were peaked in length with 20 $\mathrm{mm}$ nominal bar length at $15,12,14$ and $13 \mathrm{~cm}$ in length, respectively. Beside, S. scriba peaked in length with $18 \mathrm{~mm}$ nominal bar length at $13 \mathrm{~cm}$ in length. In all species, the length of the individuals were increased as the nominal bar length increased (Fig. 5)

The most suitable selectivity models were calculated according to minimum deviation values for each species. Within the species, bi modal was selected for $S$. scriba and $S$. tinca, log normal was selected for S.porcus and S.maena and gamma model was selected for $P$. acarne. (Table 2).

Optimum lengths and spread values (Table 3 ) and selectivity curves (Fig. 6) were calculated for S. scriba, S. tinca, S. maena, $S$. porcus and $P$. acarne as 18,20 and $22 \mathrm{~mm}$ nominal bar length respectively. 
Table 1. Catch number, length and weight values of the Non target fish species caught by 18,20 and $22 \mathrm{~mm}$ red mullet gill nets

\begin{tabular}{|c|c|c|c|c|c|c|c|c|}
\hline \multirow{2}{*}{ Species } & \multirow{2}{*}{$\begin{array}{l}\text { Nominal } \\
\text { Bar Length } \\
\quad(\mathrm{mm})\end{array}$} & \multirow[b]{2}{*}{$\begin{array}{l}\text { Number } \\
\text { (n) }\end{array}$} & \multicolumn{3}{|c|}{ Length Value } & \multicolumn{3}{|c|}{ Weight Value } \\
\hline & & & $\begin{array}{l}\text { Minimum } \\
\text { Length }(\mathrm{cm})\end{array}$ & $\begin{array}{l}\text { Maximum } \\
\text { Length }(\mathrm{cm})\end{array}$ & $\begin{array}{l}\text { Mean Length } \\
\text { and Standard } \\
\text { error }(\mathrm{cm})\end{array}$ & $\begin{array}{l}\text { Minimum } \\
\text { Weight } \\
\text { (g) }\end{array}$ & $\begin{array}{l}\text { Maximum } \\
\text { Weight (g) }\end{array}$ & $\begin{array}{l}\text { Mean Weight and } \\
\text { Standard error }(\mathrm{g})\end{array}$ \\
\hline & 18 & 201 & 12.3 & 22.4 & $14.70 \pm 1.53$ & 22 & 167 & $44.32 \pm 17.79$ \\
\hline Serranus & 20 & 128 & 13.8 & 25.3 & $17.14 \pm 1.89$ & 34 & 218 & $73.45 \pm 28.95$ \\
\hline \multirow[t]{2}{*}{ scriba } & 22 & 74 & 11.3 & 29.7 & $17.49 \pm 2.65$ & 23 & 411 & $79.82 \pm 48.23$ \\
\hline & Total & 403 & 11.3 & 29.7 & $16.44 \pm 2.02$ & 22 & 167 & $65.86 \pm 31.66$ \\
\hline & 18 & 78 & 9.5 & 18.7 & $12.17 \pm 1.47$ & 18 & 106 & $29.31 \pm 12.62$ \\
\hline Symphodus & 20 & 78 & 10 & 18.8 & $13.91 \pm 1.43$ & 17 & 122 & $40.14 \pm 14.17$ \\
\hline \multirow[t]{3}{*}{ tinca } & 22 & 51 & 13 & 17.4 & $14.70 \pm 1.03$ & 34 & 421 & $47.61 \pm 10.37$ \\
\hline & Total & 207 & 9.5 & 17.4 & $13.6 \pm 1.31$ & 17 & 106 & $39.02 \pm 12.39$ \\
\hline & 18 & 188 & 9.8 & 19 & $14.38 \pm 1.21$ & 10 & 68 & $37.72 \pm 8.59$ \\
\hline Spicara & 20 & 225 & 10.1 & 19.5 & $15.41 \pm 1.25$ & 12 & 93 & $48.55 \pm 12.68$ \\
\hline \multirow[t]{2}{*}{ maena } & 22 & 165 & 13 & 19.5 & $16.07 \pm 1.18$ & 31 & 84 & $54.99 \pm 11.05$ \\
\hline & Total & 576 & 9.8 & 19 & $15.29 \pm 1.21$ & 10 & 68 & $47.09 \pm 10.77$ \\
\hline & 18 & 19 & 10.1 & 25.5 & $14.65 \pm 3.85$ & 20 & 273 & $66.95 \pm 59.85$ \\
\hline & 20 & 42 & 11 & 21.3 & $14.09 \pm 2.63$ & 19 & 177 & $55.88 \pm 35.88$ \\
\hline \multirow[t]{3}{*}{ porcus } & 22 & 46 & 10.8 & 28 & $15.73 \pm 3.77$ & 19 & 471 & $84.61 \pm 82.65$ \\
\hline & Total & 107 & 10.1 & 21.3 & $14.82 \pm 3.42$ & 19 & 177 & $69.15 \pm 59.46$ \\
\hline & 18 & 40 & 12.8 & 18.5 & $14.08 \pm 0.95$ & 22 & 79 & $33.98 \pm 8.73$ \\
\hline \multirow{3}{*}{$\begin{array}{l}\text { Pagellus } \\
\text { acarne }\end{array}$} & 20 & 72 & 13.7 & 17.3 & $15.62 \pm 0.71$ & 33 & 68 & $46.63 \pm 6.16$ \\
\hline & 22 & 47 & 13.3 & 18.2 & $16.00 \pm 1.10$ & 35 & 80 & $51.94 \pm 9.65$ \\
\hline & Total & 159 & 12.8 & 17.3 & $15.23 \pm 0.92$ & 22 & 68 & $44.18 \pm 8.18$ \\
\hline
\end{tabular}
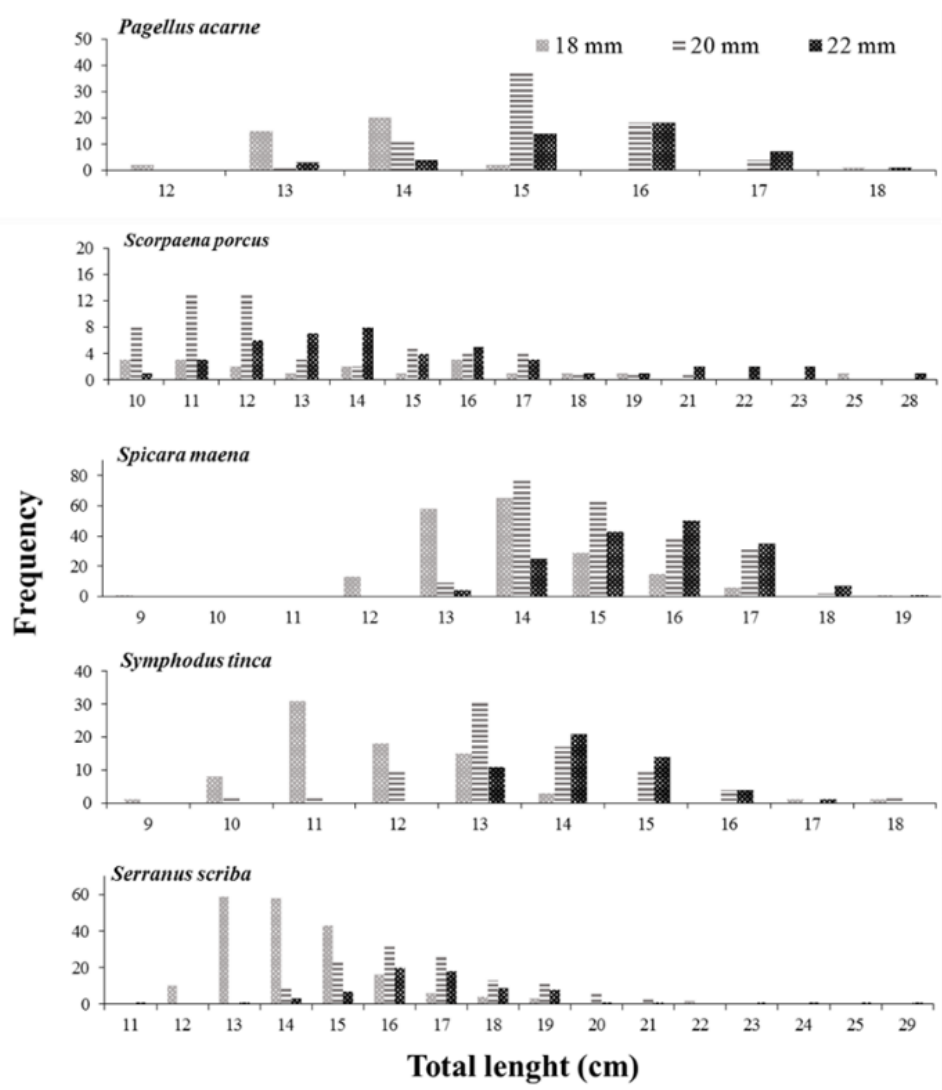

Figure 5. Length - frequency distribution of caught non target fish species 
Table 2. Selectivity parameter values of non target fish species

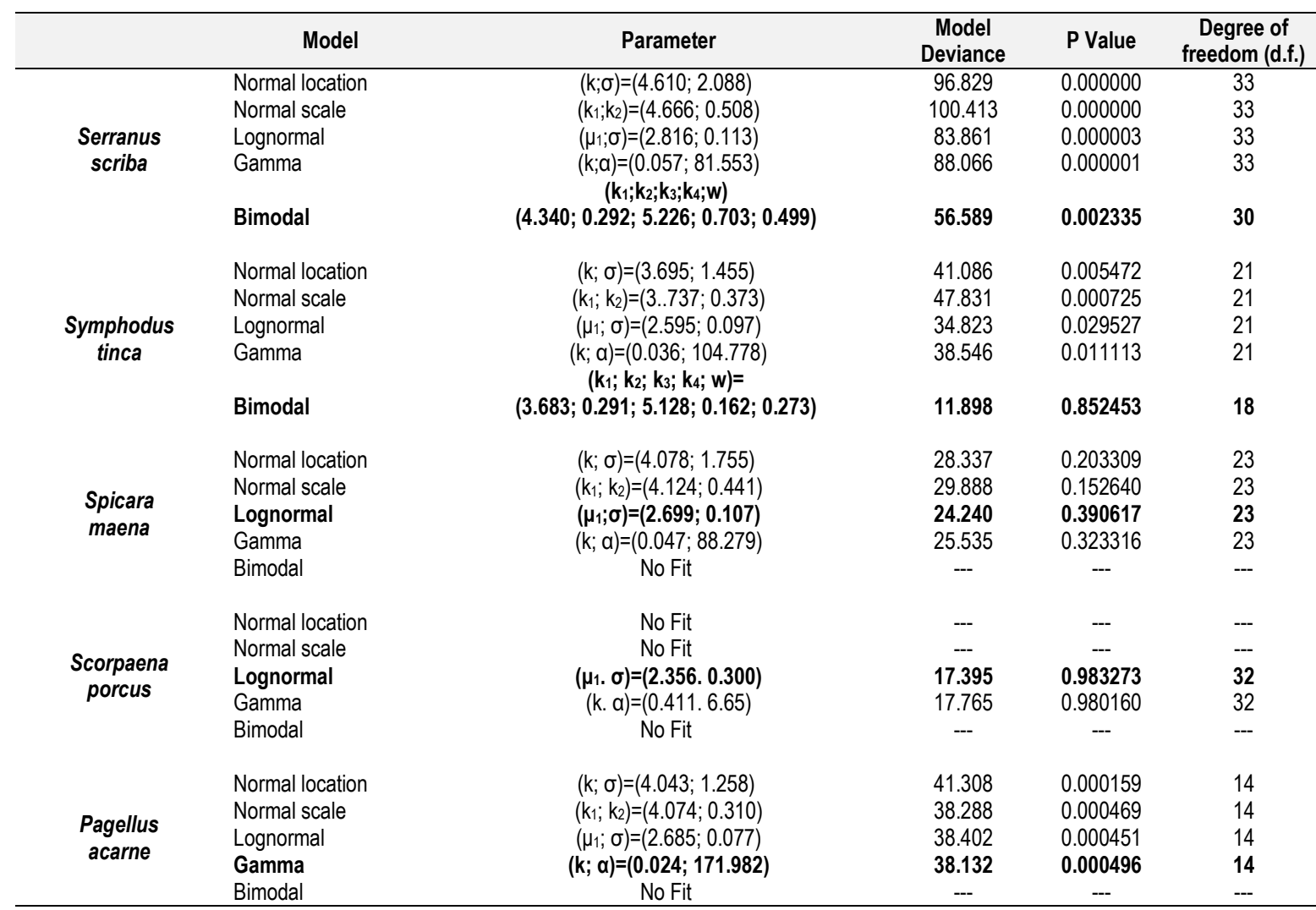

Table 3. Optimum length and spread values of the caught non target fish species

\begin{tabular}{llccc}
\hline Species & Model & Mesh size & $\begin{array}{c}\text { Opt. length } \\
\text { (cm) }\end{array}$ & $\begin{array}{c}\text { Spread } \\
\text { (cm) }\end{array}$ \\
\hline \multirow{2}{*}{ Serranus scriba } & \multirow{3}{*}{ Bimodal } & $18 \mathrm{~mm}$ & 15.62 & 1.05 \\
& & $20 \mathrm{~mm}$ & 17.36 & 1.17 \\
\multirow{2}{*}{ Symphodus tinca } & \multirow{3}{*}{ Bimodal } & $22 \mathrm{~mm}$ & 19.10 & 1.28 \\
& & $18 \mathrm{~mm}$ & 13.26 & 1.05 \\
& \multirow{3}{*}{ Spicara maena } & $20 \mathrm{~mm}$ & 14.73 & 1.17 \\
& \multirow{3}{*}{ Lognormal } & $22 \mathrm{~mm}$ & 16.21 & 1.28 \\
\hline \multirow{3}{*}{ Scorpaena porcus } & & $18 \mathrm{~mm}$ & 14.70 & 1.60 \\
& \multirow{3}{*}{ Pagellus acarne } & $20 \mathrm{~mm}$ & 16.33 & 1.78 \\
& & $22 \mathrm{~mm}$ & 17.96 & 1.96 \\
\hline
\end{tabular}


Table 4. Comparison of the selectivity studies deal with the same species

\begin{tabular}{|c|c|c|c|c|c|c|}
\hline Species & Method & Area & $\begin{array}{l}\text { Mesh size } \\
\quad(\mathrm{mm})\end{array}$ & $\begin{array}{l}\text { Optimum } \\
\text { length } \\
\text { (cm) }\end{array}$ & $\begin{array}{l}\text { Spread } \\
(\mathrm{cm})\end{array}$ & Referance \\
\hline \multirow[b]{2}{*}{$\begin{array}{l}\text { Serranus } \\
\text { scriba }\end{array}$} & HOLT & $\begin{array}{l}\text { Central Aegean Sea } \\
\text { (Marmara Sea) }\end{array}$ & $\begin{array}{l}18 \\
20 \\
22\end{array}$ & $\begin{array}{l}14.74 \\
16.38 \\
18.02\end{array}$ & & Kınacıgil et al. (2000) \\
\hline & $\begin{array}{l}\text { SELECT } \\
\text { bi-modal }\end{array}$ & $\begin{array}{c}\text { Çanakkale shores } \\
\text { (Marmara Sea) }\end{array}$ & $\begin{array}{l}18 \\
20 \\
22 \\
\end{array}$ & $\begin{array}{l}15.62 \\
17.36 \\
19.10 \\
\end{array}$ & $\begin{array}{l}1.05 \\
1.17 \\
1.28\end{array}$ & In this study \\
\hline $\begin{array}{l}\text { Symphodus } \\
\text { tinca }\end{array}$ & $\begin{array}{l}\text { SELECT } \\
\text { bi-modal }\end{array}$ & $\begin{array}{c}\text { Çanakkale shores } \\
\text { (Marmara Sea) }\end{array}$ & $\begin{array}{l}18 \\
20 \\
22 \\
\end{array}$ & $\begin{array}{l}13.26 \\
14.73 \\
16.21 \\
\end{array}$ & $\begin{array}{l}1.05 \\
1.17 \\
1.28 \\
\end{array}$ & In this study \\
\hline \multirow{4}{*}{$\begin{array}{l}\text { Spicara } \\
\text { maena }\end{array}$} & $\begin{array}{l}\text { SELECT } \\
\text { bi-modal }\end{array}$ & $\begin{array}{c}\text { Gökçeada } \\
\text { (North Aegean Sea) }\end{array}$ & $\begin{array}{l}18 \\
20 \\
22 \\
\end{array}$ & $\begin{array}{l}15.10 \\
16.78 \\
18.46 \\
\end{array}$ & $\begin{array}{l}1.07 \\
1.19 \\
1.30 \\
\end{array}$ & $\begin{array}{l}\text { Karakulak and Erk, } \\
\qquad(2008)\end{array}$ \\
\hline & $\begin{array}{l}\text { SELECT } \\
\text { lognormal }\end{array}$ & $\begin{array}{c}\text { Cyclades Island } \\
\text { (Aegean Sea) }\end{array}$ & $\begin{array}{l}22 \\
24 \\
26 \\
28\end{array}$ & $\begin{array}{l}18.54 \\
20.23 \\
21.92 \\
23.60\end{array}$ & $\begin{array}{l}1.91 \\
2.08 \\
2.25 \\
2.43\end{array}$ & $\begin{array}{l}\text { Stergiou and Erzini, } \\
(2002)\end{array}$ \\
\hline & HOLT & $\begin{array}{c}\text { Izmır Bay } \\
\text { (Aegeam Sea) }\end{array}$ & $\begin{array}{l}18 \\
20 \\
22\end{array}$ & $\begin{array}{l}15.00 \\
16.67 \\
18.33\end{array}$ & & Metin et al. (1998) \\
\hline & $\begin{array}{l}\text { SELECT } \\
\text { lognormal }\end{array}$ & $\begin{array}{l}\text { Çanakkale shores } \\
\text { (Marmara Sea) }\end{array}$ & $\begin{array}{l}18 \\
20 \\
22 \\
\end{array}$ & $\begin{array}{l}14.70 \\
16.33 \\
17.96 \\
\end{array}$ & $\begin{array}{l}1.60 \\
1.78 \\
1.96 \\
\end{array}$ & In this study \\
\hline $\begin{array}{c}\text { Scorpaena } \\
\text { porcus }\end{array}$ & $\begin{array}{l}\text { SELECT } \\
\text { lognormal }\end{array}$ & $\begin{array}{c}\text { Çanakkale kıyıları } \\
\text { (Marmara Sea) }\end{array}$ & $\begin{array}{l}18 \\
20 \\
22 \\
\end{array}$ & $\begin{array}{c}9.64 \\
10.71 \\
11.78 \\
\end{array}$ & $\begin{array}{l}3.39 \\
3.76 \\
4.14 \\
\end{array}$ & In this study \\
\hline \multirow{3}{*}{$\begin{array}{l}\text { Pagellus } \\
\text { acarne }\end{array}$} & $\begin{array}{l}\text { SELECT/ } \\
\text { bi-modal }\end{array}$ & $\begin{array}{c}\text { Gökçeada } \\
\text { (Kuzey Ege Denizi) }\end{array}$ & $\begin{array}{l}18 \\
20 \\
22\end{array}$ & $\begin{array}{l}13.71 \\
15.23 \\
16.76 \\
\end{array}$ & $\begin{array}{l}0.57 \\
0.63 \\
0.69\end{array}$ & $\begin{array}{l}\text { Karakulak and Erk, } \\
\qquad(2008)\end{array}$ \\
\hline & $\begin{array}{c}\text { Direct } \\
\text { Estimation } \\
\text { Method }\end{array}$ & $\begin{array}{l}\text { Izmır Bay, Urla } \\
\text { (Aegean Sea) }\end{array}$ & 18 & 13.7 & & Illkyaz, (2005) \\
\hline & $\begin{array}{l}\text { SELECT/ } \\
\text { bi-modal }\end{array}$ & $\begin{array}{c}\text { Çanakkale shores } \\
\text { (Marmara Sea) }\end{array}$ & $\begin{array}{l}18 \\
20 \\
22\end{array}$ & $\begin{array}{l}12.31 \\
13.68 \\
15.05\end{array}$ & $\begin{array}{l}0.94 \\
1.05 \\
1.15\end{array}$ & In this study \\
\hline
\end{tabular}

Table 5. The length at first maturity of fish species caught in this study

\begin{tabular}{|c|c|c|c|}
\hline Species & Area & The Length at First Maturity $(\mathrm{cm})$ & Referance \\
\hline $\begin{array}{l}\text { Serranus } \\
\text { scriba }\end{array}$ & $\begin{array}{c}\text { Lanzarote Island } \\
\text { (Middle East Adriatic) } \\
\text { Trigor Bay } \\
\text { (Middle East Adriatic) }\end{array}$ & 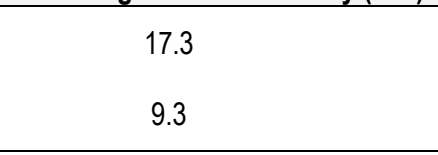 & $\begin{array}{l}\text { Tuset et al. (2005) } \\
\text { Zorica et al. (2006) }\end{array}$ \\
\hline $\begin{array}{c}\text { Symphodus } \\
\text { tinca }\end{array}$ & $\begin{array}{c}\text { Sfax shores } \\
\text { ( Tunusia ) }\end{array}$ & Males 13.1; Females 13.4 & Ghorbel et al. (2002) \\
\hline $\begin{array}{l}\text { Spicara } \\
\text { maena }\end{array}$ & $\begin{array}{c}\text { İzmir Bay } \\
\text { ( Aegean Sea ) }\end{array}$ & Males 13.1; Females 11.5 & Kınacıgil et al. (2008) \\
\hline $\begin{array}{l}\text { Scorpaena } \\
\text { porcus }\end{array}$ & $\begin{array}{c}\text { Sinop shores } \\
\text { (Black Sea) } \\
\text { Sinop shores } \\
\text { (Black Sea) }\end{array}$ & $\begin{array}{l}\text { Males 16.7; Female } 17.5 \\
20 \text { (3rd and 4th ages) }\end{array}$ & $\begin{array}{l}\text { Bilgin and Çelik (2009) } \\
\text { Koca. (2002) }\end{array}$ \\
\hline $\begin{array}{l}\text { Pagellus } \\
\text { acarne }\end{array}$ & $\begin{array}{c}\text { Saroz Bay ( North Aegean Sea) } \\
\text { İzmir Bay ( Aegean Sea ) } \\
\text { Mediterranean } \\
\text { Aegean Sea }\end{array}$ & $\begin{array}{c}\text { Males 15.3; Females } 18.1 \\
\text { Males 13.9; Females } 14.5 \\
\text { Males 13; Females } 18 \\
11 \\
\end{array}$ & $\begin{array}{c}\text { Ismen et al. (2010) } \\
\text { Kınacıgil et al. (2008) } \\
\text { Whitehead et al. (1986) } \\
\text { JICA (1993) } \\
\end{array}$ \\
\hline
\end{tabular}




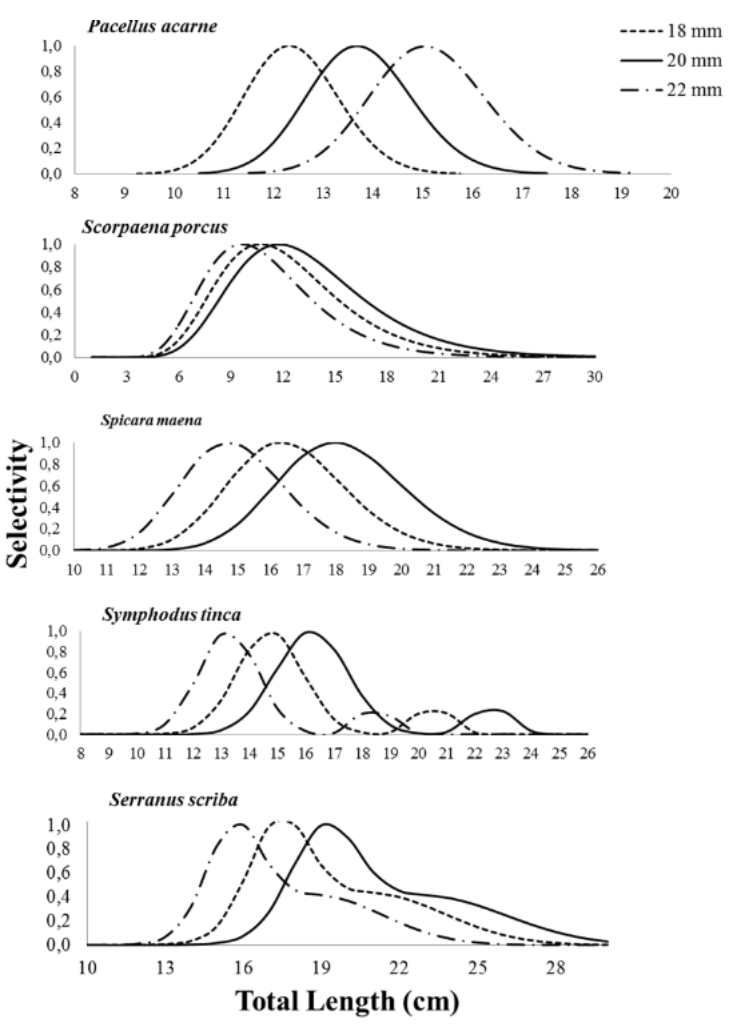

Figure 6. Selectivity curves of the caught non target fish species according to mesh sizes

\section{CONCLUSION}

The selectivity results of the species varied between studies, due to using varied methods and models for analyzing selectivity pattern. The selectivity values may vary depending on the fish morphometrics (length, body shape etc.), geographical differences and gillnet properties (nominal bar length, net material, hanginig ratio etc.).

It has been observed that the selectivity parameters of the species showed differences when compared to previous studies. Kınacıgil et al. (2000) have found a smaller optimum length at each mesh for $\mathrm{S}$. scriba even though used gillnets with the same nominal bar length. It is thought that this difference is caused by using different model and sample size (Table 4).

First maturity length is important for evaluating selectivity. Due to the sustainability of the stocks, offsprings get at least one chance to spawn. The first maturity length of $S$. scriba was determined as $17.3 \mathrm{~cm}$ (Tuset et al., 2005) in Lanzarote Island (Table 5). Whereas optimum catch length in this study was determined as $19.1 \mathrm{~cm}$ at $22 \mathrm{~mm}$ nominal bar length. The use of a smaller nominal bar length than $22 \mathrm{~mm}$ is thought to be unsuitable for sustainability of stocks.

Ghorbel et al. (2002) indicated that first maturity length of $S$. tinca was $13.1 \mathrm{~cm}$ for males and $13.4 \mathrm{~cm}$ for females around Sfax shores of Morocco (Table 5). In our study shows that optimum catch length of the 18,20 and $22 \mathrm{~mm}$ nominal bar length of S. tinca were 13.3, 14.7 and $16.2 \mathrm{~cm}$, respectively. So, 18 and $20 \mathrm{~mm}$ mesh size could endanger regenerating of the stocks.

First maturity length of $S$. maena was detected as $13.1 \mathrm{~cm}$ for males and $11.5 \mathrm{~cm}$ for females (Kinacigil et al., 2008) (Table 5). The optimum catch length and spread value in minimum mesh size in our study were calculated as 14.7 and $1.6 \mathrm{~cm}$, respectively. The results appear to be similar to those of other studies where selectivity of $\mathrm{S}$. maena is calculated (Metin et al., 1998; Karakulak and Erk, 2008) (Table 4). Conversely, in the work carried out by Stergio and Erzini (2002), a higher optimum catch length was detected. These differences can be explained by the geographical differences and varied environmental parameters. Consequently, it is thought that only $18 \mathrm{~mm}$ of nominal bar length can cause of threat on the stocks with a slight possibility.

Bilgin and Çelik (2009) confirmed that first maturity length of $S$. porcus was $16.5 \mathrm{~cm}$ for males and $17.5 \mathrm{~cm}$ for females (Table 5). Whereas optimum catch lengths were calculated as 9.6, 10.7 and $11.8 \mathrm{~cm}$ from 18, 20 and $22 \mathrm{~mm}$ nominal bar length, respectively. There is a significantly difference between first maturity length and optimum catch length. It can be thought that this difference is not significant due to having lots of spines around the gills. It is clear that any nominal bar length or gillnet will have an adverse effect on the stocks of $S$. porcus.

Issmen et al. (2010) were calculated the first maturity length of $P$. acarne in Saros Bay as $15.3 \mathrm{~cm}$ for males and $18.1 \mathrm{~cm}$ for females (Table 5). In this study, optimum catch length of $P$. acarne were found $12.3,13.7$ and $15.1 \mathrm{~cm}$ from 18,20 and 22 $\mathrm{mm}$ nominal bar lengths, respectively. These results are similar to those of other studies (Karakulak and Erk, 2008; Illkyaz, 2005) (Table 4). Both the fact that all of the optimum catch length values are smaller than the first maturity length and the similar results in three different studies indicate that the stocks of $P$. acarne are affected in a dangerous manner by the red mullet gillnet fisheries.

In conclusion, it is evident that commersial red mullet gillnets has highly hazardious effects on non target fish species. Both using higher than $22 \mathrm{~mm}$ nominal bar length and 0.5 hanging ratio may serve as protective measures. Undoubtedly that the selectivity results for each species contribute to fisheries management. In terms of ecosystem-based fisheries management, studies that examine the potential adverse effects of each fishing tool on all living organisms should be increased. These findings enhance our understanding of the importance of selectivity of the non target fish species.

\section{ACKNOWLEDGMENTS}

This study supported by Tübitak 106Y021 numbered Project. Results of this study contains a part of Msc thesis of Engin Kocabaş. Thanks are extended to Cahit Ceviz and Osman Odabaşı. 


\section{REFERENCES}

Ayaz, A., İşmen, A., Özekinci, U., Altınağaç, U., Özen, Ö., Yığın, C.Ç., Cengiz, Ö., Ayyıldız, H. \& Öztekin, A. (2010a). Studies on Determining By-catch Ratio and Bottom Gill Net Selectivity in north Aegean Sea. Project Report. TÜBITAK 106Y021. (in Turkish).

Ayaz, A., Ünal, V., Acarli, D. \& Altınağaç, U. (2010b). Fishing Gear Losses in the Gökova Special Environmental Protection Area (SEPA), eastern Mediterranean, Turkey. Journal of Applied Ichthyology, 26, 416-419. DOI: 10.1111/j.1439-0426.2009.01386.x

Aydın, I., Gökçe, G. \& Metin, C. (2008). The Effects of Netting Twine on Discard Rates of Commercial Red Mullet Gillnets in Izmir Bay. Turkish Journal of Fisheries and Aquatic Sciences, 8, 373-376.

Aydın, I., Gökçe, G. \& Metin, C. (2013). Using Guarding Net to Reduce Regularly Discarded Invertebrates in Trammel Net Fisheries Operating on Seagrass Meadows (Posidonia oceanica) in İzmir Bay (Eastern Aegean Sea). Mediterranean Marine Science, 14(2), 282-291.

Bilgin, S. \& Çelik, E.S. (2009). Age, Growth and Reproduction of the Black Scorpionfish, Scorpaena porcus (Pisces, Scorpaenidae), on the Black Sea coast of Turkey. Journal of Applied Ichthyology, 25, 55-60. DOI: 10.1111/j.1439-0426.2008.01157.x

Ghorbel, A.O., Bradai, M.N. \& Bouain, A. (2002). Spawning Period and Sexual Maturity of Symphodus (Crenilabrus) tinca (Labridae) in Sfax Coasts (Tunisia). Cybium, 26(2), 89-92 (in French).

Guland, J.A. (1983). Fish Stock Assessment. A Manual of Basic Methods $225 p$.

Hamley, J.M. (1975). Review of Gillnet Selectivity. Journal of the Fisheries Research Board of Canada, 32(11), 1943-1969. DOI: 10.1139/f75-233

Holt, S.J. (1963). A Method for Determining Gear Selectivity and Its Application Convention for the Northwest Atlantic Fisheries Special Publication, 5 : 106-115.

Hovgard, H. \& Lassen, H. (2000). Manual on Estimation of Selectivity for Gillnet and Longline Gears in Abundance Surveys. FAO Fisheries Technical Paper No:397, Rome, FAO, p. 84

İlkyaz, A.T. (2005). Determining Selectivity Parameters of Gillnets with Direct Estimation Method. pHd Thesis: Izmir: Ege University. 131p. (in Turkish).

İşmen, A., Özekinci, U., Özen, Ö., Ayaz, A., Altınağaç, U., Yığın, C.Ç., Ayyıldız, H., Cengiz, Ö., Arslan, M., Ormancı, H.B., Çakır, F. \& Öz, M.İ. (2010). Determining Bio-ecology and Population Dynamics of of Demersal Fishes in Saros Bay. Project Report. TÜBITAK 106Y035. (in Turkish)

JICA. (1993). Report of Demersal Fisheries Resources Survey in the Republic of Turkey.

Karakulak, F.S. \& Erk, H. (2008). Gillnet and Trammel net Selectivity in the northern Aegean Sea, Turkey. Scienta Marina, 72: 527-540. DOI: 10.3989/scimar.2008.72n3527

Kelleher, K. (2005). Discards in the World's Marine Fisheries. An update. FAO Fisheries Technical Paper. Roma. ISBN: 92-5-105289-1.

Kınacıgil, H.T., İlkyaz, A.T., Ayaz, A., Akyol, O. \& Altınağaç, U. (2000) Research on Effects of Gillnets on Fish Populations in Central Aegean Sea. Project Report, TÜBITAK 198Y023. (in Turkish).

Kınacıgil, T.H., Illkyaz, T.A, Metin, G., Ulaş, A., Soykan, O., Akyol, O. \& Gurbet R. (2008). Determining the first reproduction length, age and growth parameters of Aegean Sea demersal fish for the regulation of fisheries management, (in Turkish). The Scientific and Technological Research Counci I of Turkey (TUBITAK) 103Y132, Final Report, İzmir, 327 pp.
Koca, H.U. (2002). A Study on the Determination of Some Parameters of the Scorpion Fish (Scorpaena porcus Linne, 1758) Caught by Bottom Nets in the Area of Sinop in Terms of Fishery Biology. Turkish Journal of Veterinary and Animal Sciences, 26: 65-69. (in Turkish).

Kolding, J. \& Skålevik, Å. (2011). PasGear 2. A Database Package for Experimental or Artisanal Fishery Data. Version 2.5.

Martin, P., Sartor, P. \& Garcia-Rodriguez, M. (1999). Exploitation patterns of the European hake Merluccius merluccius, red mullet Mullus barbatus and striped red mullet Mullus surmuletus in the western Mediterranean. Journal of Applied Ichthyology, 15: 24-28.

DOI: 10.1046/j.1439-0426.1999.00125.X

Metin, C., Lök, A. \& Illkyaz, T.A. (1998). The Selectivity of Gillnet in Different Mesh Size for Diplodus annularis (Linn.,1758) and Spicara flexuosa (Rafinesque, 1810). Ege Journal of Fisheries and Aquatic Sciences, 15, 293-303. (in Turkish)

Millar, R.B. (1992). Estimating the Size-Selectivity of Fishing Gear by Conditioning on the Total Catch. Journal of the American Statistical Association, 87(420): 962-968. DOI: 10.1080/01621459.1992.10476250

Millar, R.B. \& Fryer, R.J. (1999). Estimating the Size-selection Curves of Towed Gears, Traps, Nets and Hooks. Reviews in Fish Biology and Fisheries, 9: 89-116. DOI: 10.1023/A:1008838220001

Millar, R.B. \& Holst, R. (1997). Estimation of Gillnet and Hook Selectivity Using Log-linear Models. ICES Journal of Marine Science. 54, 471-477. DOI: 10.1006/jmsc.1996.0196

Papaconstantinou, C. \& Farrugio, H. (2000). Fisheries in the Mediterranean. Mediterranean Marine Science, 1(1), 5-18. DOI: 10.12681/mms.2

Reis, E.G. \& Pawson, M.G. (1992). Determination of Gill-net Selectivity for Bass (Dicentrarchus-labrax L) Using Commercial Catch Data. Fisheries Research, 13, 173-187. DOI: 10.1016/0165-7836(92)90025-O

Sbrana, M., Belcari, P., De Ranieri, S., Sartor, P. \& Viva, C. (2007). Comparison of the Catches of European hake (Merluccius merluccius, L. 1758) Taken with Experimental Gillnets of Different Mesh Sizes in the northern Tyrrhenian Sea (western Mediterranean). Scienta Marina, 71, 47-56. DOI: $10.3989 /$ scimar.2007.71n147

Stergiou, K.I. \& Erzini, K. (2002). Comparative Fixed Gear Studies in the Cyclades (Aegean Sea): Size Selectivity of Small-hook Longlines and Monofilament Gill nets. Fisheries Research, 58, 25-40. DOI: 10.1016/S0165-7836(01)00363-0

Tuset, V.M., García-Díaza, M.M., Gonzáleza, J.A., Lorenteb, M.J. \& Lozanoc I.J. (2005). Reproduction and Growth of the Painted Comber Serranus scriba (Serranidae) of the Marine Reserve of Lanzarote Island (CentralEastern Atlantic), Estuarine. Estuarine, Coastal and Shelf Science, 64, 335-346. DOI: 10.1016/j.ecss.2005.02.026

Whitehead, P.J.P., Bauchot, M., Hureau, J.C., Nielsen, J. \& Tortonese, E. (1986). Fishes of the North-eastern Atlantic and the Mediterranean, Volume I, II and III, UNESCO, Paris, Paris.

Zorica, B., Sinovčić, G., Pallaoro, A. \& Čikeš, Keč V. (2006). Reproductive Biology and Length-Weight Relationship of Painted Comber, Serranus scriba (Linnaeus, 1758), in the Trogir Bay Area (Middle-eastern Adriatic). Journal of Applied Ichthyology, 22, 260-263. DOI: 10.1111/j.1439-0426.2006.00632.x 